\title{
First report of the Southern Gulf Coast Toad (Incilius valliceps Wiegmann), Common House Gecko (Hemidactylus frenatus Duméril and Bibron), Schmidt's Black-Striped Snake (Coniophanes schmidti Bailey), and Cozumel Whiptail (Aspidoscelis cozumela Gadow), on Turneffe Atoll, Belize
}

\author{
John R. Finnerty ${ }^{1,2, *} \mathbb{D}$, Karina Scavo Lord ${ }^{1,2}$, Tina Barbasch ${ }^{1,2}\left(\mathbb{D}\right.$, Russell Laman ${ }^{1,2}$, Lara Hakam ${ }^{1,2}$, \\ Raziel Perez', Heather Jenkins², Brad J. Fortunato 1,2, Clint Lockwood', David Bianco-Caron',2, and \\ Nathan L. Stewart ${ }^{1,3}$ \\ 'Boston University Marine Program and ²Department of Biology, Boston University, 5 Cummington Mall, Boston, MA 02215, USA. \\ ${ }^{3}$ Current address: Sustainability Studies Program, Colorado Mountain College, 1275 Crawford Ave, Steamboat Springs, CO 80487, USA. \\ *Corresponding author (jrf3@bu.edu)
}

Edited by: Robert Powell. Date of publication: 22 December 2021.

Citation: Finnerty JR, Lord KS, Barbasch T, Laman R, Hakam L, Perez R, Jenkins H, Fortunato BJ, Lockwood C, Bianco-Caron D, Stewart NL (2021) First report of the Southern Gulf Coast Toad (Incilius valliceps Wiegmann), Common House Gecko (Hemidactylus frenatus Duméril and Bibron), Schmidt's Black-Striped Snake (Coniophanes schmidti Bailey), and Cozumel Whiptail (Aspidoscelis cozumela Gadow), on Turneffe Atoll, Belize. Caribbean Herpetology, 81, 1-14

DOI: https://doi.org/10.31611/ch.81

\begin{abstract}
Each year from 2012 to 2019, during a 12-day period in November or December, we photographed common herpetofauna on Calabash Caye, a small mangrove-dominated island on the eastern edge of Turneffe Atoll, Belize. Turneffe Atoll is home to the newest, largest, and most biodiverse marine protected area in Belize. Calabash Caye exemplifies the islands on Turneffe's eastern edge whose elevated beach ridges enable the development of coastal strand plain and littoral forest habitats, which are among the most threatened habitats in the world. As no herpetofaunal survey has been published for Turneffe in over twenty years, and as the herpetofauna is a conspicuous indicator of the health of terrestrial ecological communities on islands, we leveraged our annual field excursions to Calabash Caye to compile a photographic record of the island's reptiles and amphibians. In multiple years, we documented the presence of five lizards (Anolis sagrei mayensis, Aspidoscelis cozumela, Ctenosaura similis, Phyllodactylus tuberculosus, and the invasive species Hemidactylus frenatus), three snakes (Boa imperator, Leptophis mexicanus hoeversi, and Coniophanes schmidti), and one amphibian (Incilius valliceps). This represents the first report of A. cozumela, H. frenatus, $C$. schmidti, and $I$. valliceps on Calabash Caye or on any island in Turneffe Atoll; H. frenatus, C. schmidti, and I. valliceps have never been reported on any of the Belizean cayes. We did not observe four species that have previously been reported on Calabash Caye: Brown Basilisk (Basiliscus vittatus), Mesoamerican Cane Toad (Rhinella horribilis), Mayan Skink (Marisora lineola; formerly Mabuya unimarginata), or a blindsnake, provisionally identified as Indotyphlops braminus. We also include photos of Anolis allisoni, Ctenosaura similis, and Anolis sagrei mayensis obtained during four single-day excursions to Half Moon Caye on Lighthouse Atoll; this represents three of four species reported from that location during the 1990 s.
\end{abstract}

Keywords: Amphibian, Calabash Caye, Caribbean, conservation, distribution, introduced species, invasive species, reptile.

\section{Introduction}

Turneffe Atoll, located $\sim 33 \mathrm{~km}$ off the coast of Belize, represents the western extent of the "Caribbean Islands" geographic region (Hedges et al., 2019). It is also the largest oceanic atoll in the Western Hemisphere (Stoddart, 1962) and the site of Belize's newest, largest, and most biodiverse marine reserve (Turneffe Atoll Sustainability Association, 2020). While the principal management aim of the reserve is to conserve the fragile marine environments, approximately $20 \%$ of the area encompassed by Turneffe Atoll consists of terrestrial habitats, divided among hundreds of cayes, ranging in size from small sandbars to an 11,000-acre landmass (Turneffe Atoll Sustainability Association, 2020). The beaches, littoral forests, and mangrove forests found on these islands support a diverse and biologically important assemblage of terrestrial organisms (Meerman, 2006). 
Obtaining accurate species inventories is critical to the conservation and management of Turneffe, particularly to establish a baseline against which we can evaluate the ecological effects of environmental change, management decisions, or changes in the utilization of the atoll. Amphibians and reptiles are the two major vertebrate groups of endemic species on Caribbean islands (Hedges et al., 2019), and the herpetofauna is a particularly conspicuous component of the terrestrial fauna on many Belizean cayes, including those that comprise Turneffe Atoll. Reptiles, and to a lesser extent, amphibians can be highly abundant, and have a proportionately large impact on the ecology of these semi-isolated terrestrial ecosystems. Unfortunately, very few data address the abundance and diversity of terrestrial reptiles and amphibians on Turneffe Atoll, a concern that has existed for decades; indeed, no report on the overall herpetofauna of Turneffe Atoll has been published in the last twenty years, a period of accelerating environmental change and species loss (Platt et al., 1999).

To update the herpetofaunal inventory on Calabash Caye, a small mangrove-dominated island on the eastern edge of Turneffe Atoll, we compiled photographs of five species of lizards, three species of snakes, and one species of toad. All the photos were taken during one of eight 12-day field trips, undertaken in November or December of 2012 through 2019. The photographic sampling we conducted was opportunistic, documenting those species that could be observed from developed areas of the island as well as the edges of strand plain habitat and littoral forest bordering these areas. The sampling was therefore biased toward species that are relatively common, accessible, and conspicuous. Despite these sampling limitations, we obtained the first records of the Common House Gecko (Hemidactylus frenatus), Cozumel Whiptail (Aspidoscelis cozumela), Schmidt's Black-Striped Snake (Coniophanes schmidti), and Southern Gulf-Coast Toad (Incilius valliceps) on Turneffe Atoll. We also include photos of three lizards observed during four day-long excursions to Half Moon Caye on Lighthouse Atoll. All photos are accessible through the media library of the Boston University Marine Program (bumarine.smugmug.com/ORGAN-
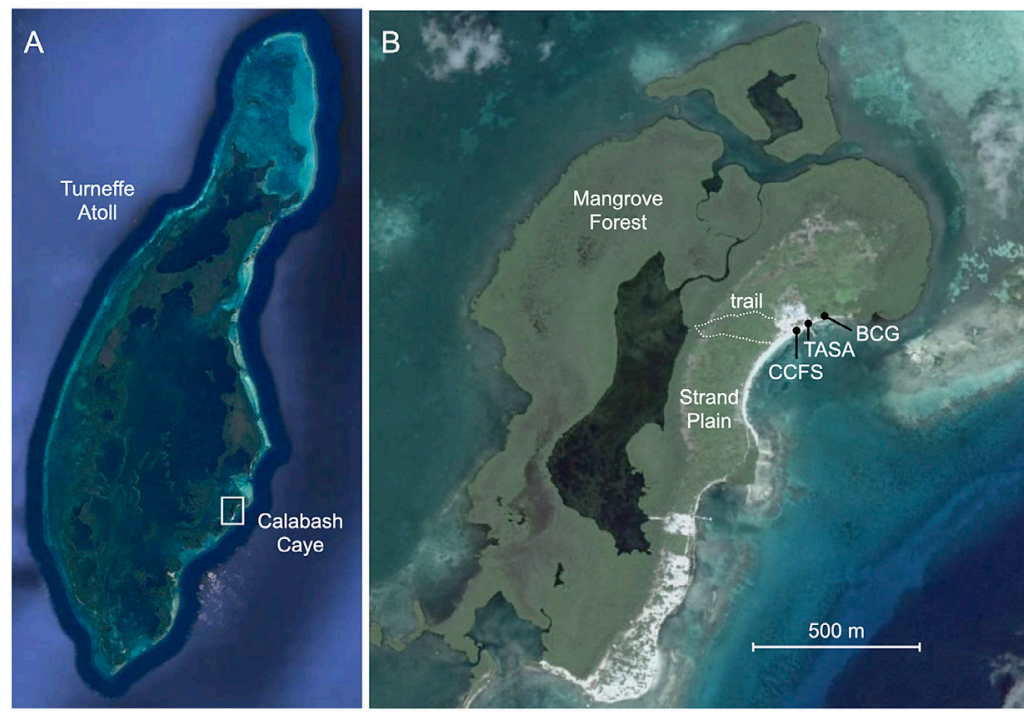

C
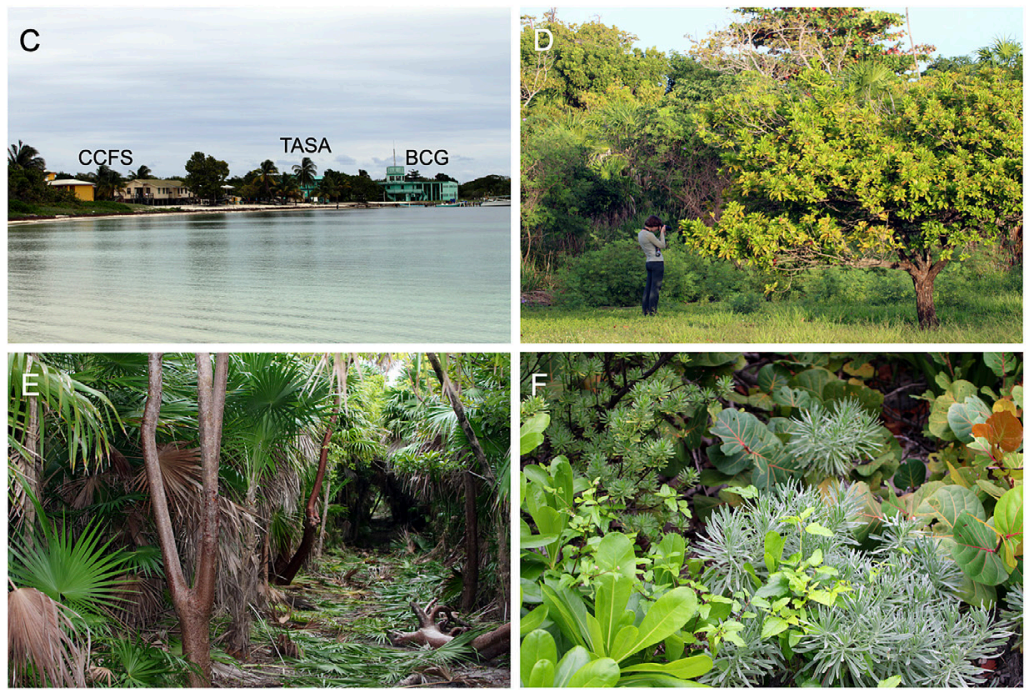

Figure 1. Study Site. Satellite views of (A) Turneffe Atoll and (B) Calabash Caye. Abbreviations are: $B C G=$ Belize Coast Guard; CCFS = Calabash Caye Field Station; TASA = Turneffe Atoll Sustainability Association. The structures built to house the Belizean Coast Guard's operating base, erected in 2010, and the Turneffe Atoll Sustainability Association's operating base, erected in 2015, are not depicted in the satellite image. (C) View of the eastern shore of Calabash Caye. (D) Manicured habitat adjacent to the trail head, west of the field station. (E) View of the trail depicting representative vegetation. (F) Representative vegetation in the strand plain habitat adjacent to the beach. Photo credits: $(A, B)$ The image is dated August 26, 2005 and was obtained using Google Earth Pro (v. 7.3.2.5776). Images ๑ ISMS/METAZOA-animals/CHORDATA). 2020 Maxar Technologies. (C, D) Photos by John R. Finnerty. 


\section{Results and Discussion}

Site Characterization. Calabash is a small mangrove island located on the eastern rim of Turneffe Atoll (Fig. 1). The sandy, eastern shore of the island is home to the Calabash Caye Field Station (CCFS), operated by the University of Belize, an office of the Turneffe Atoll Sustainability Association, and a forward operating base for the Belizean Coast Guard, as well as four private homes that are only sporadically occupied. The uninhabited portions of Calabash Caye can be divided into two major terrestrial habitats. A strand-plain habitat occupies much of the eastern third of the island, where littoral forest grows on a mixture of sand and coral rubble. Common tree species here include Bursera simaruba L., Cordia sebestena L., Coccoloba uvifera L., Conocarpus erectus L., Metopium brownei L., Ponteria campechiana (Kunth) Baehni, and Thrinax radiata Loddiges (Stoddart, 1962; Fosberg et al., 1982). The western two-thirds and northern tip of the island consist of submerged peat covered by mangrove forest, primarily
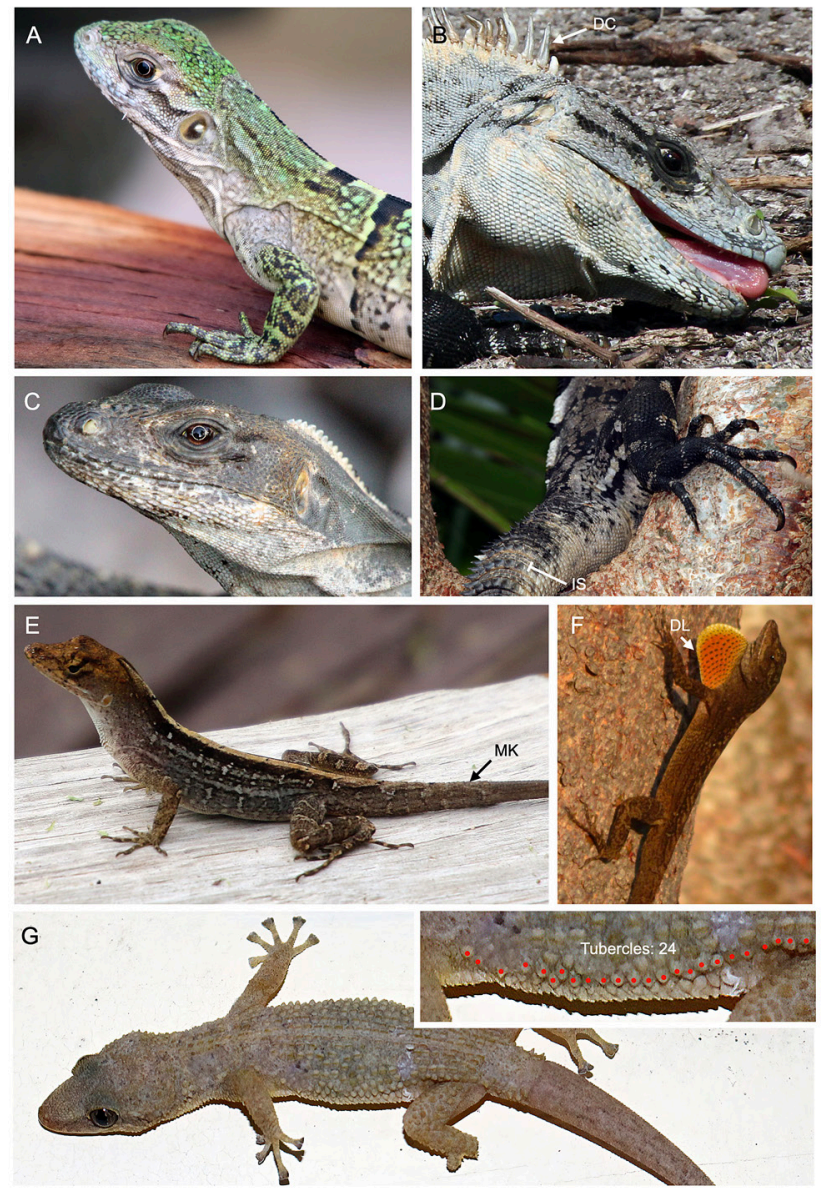

Figure 2. Lizards previously reported from Calabash Caye. Common Spiny-tailed Iguana, Ctenosaura similis: (A) juvenile (November 2015), (B) adult male feeding on vegetation (December 2012), (C) adult female (November 2014), and (D) tail of adult male clinging to a tree trunk (December 2018). Mayan Coastal Anole, Anolis sagrei mayensis: (E) resting on discarded lumber (December 2018), (F) clinging to a tree trunk (December 2018). Tuberculate Leaf-toed Gecko, Phyllodactylus tuberculosus: $(\mathrm{G})$ individual clinging to the interior wall of a building, with a partially missing right hindlimb (November 2013). Red dots in the enlargement mark individual tubercles between axilla and groin. Abbreviations: $\mathrm{DC}=$ dorsal crest; $\mathrm{DL}=$ dewlap; $\mathrm{IS}=$ intercalary scales; $M K=$ median keel. Photos by John R. Finnerty $(\mathrm{A}-\mathrm{F})$ and Lara R. Hakam (G).

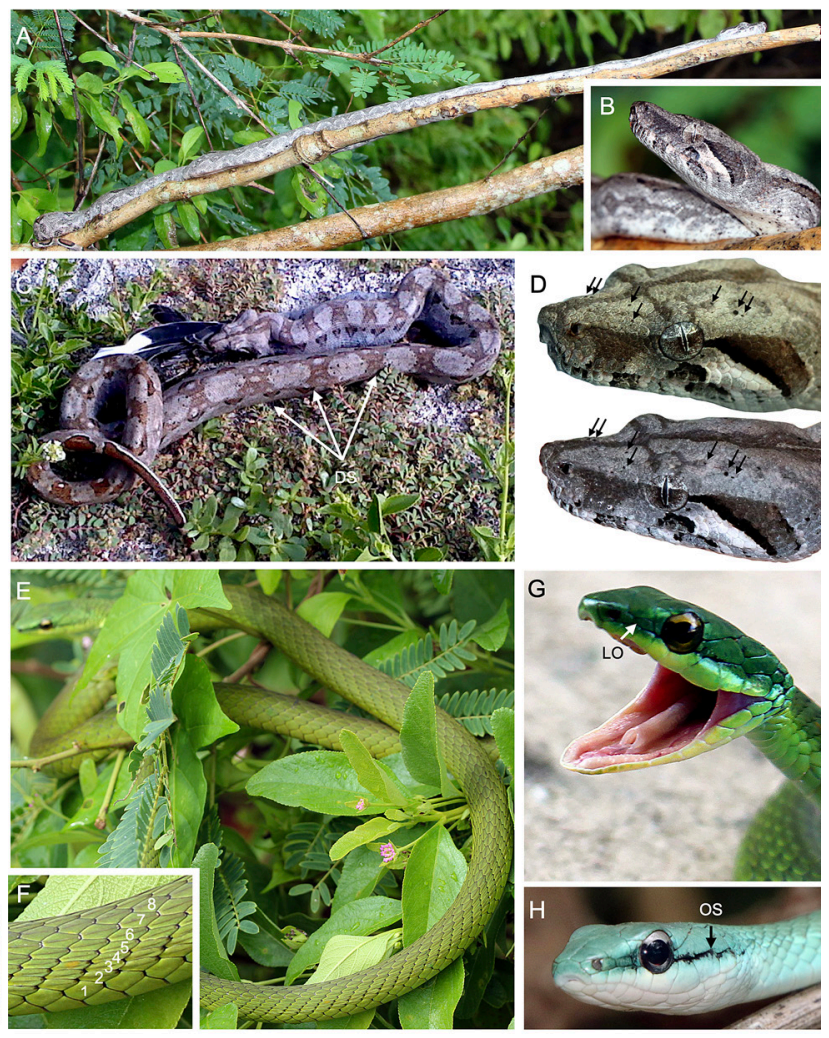

Figure 3. Snakes previously reported from Calabash Caye. Central American Boa, Boa imperator: (A) Individual photographed on the morning of 12 November 2016 in littoral forest adjacent to the walking trail, (B) enlarged view of the head of the individual shown in (A), (C) individual ingesting a grackle (September 2013), (D) lateral head views of snakes photographed in December 2017 (top) and December of 2018 (bottom). Black arrows indicate an identical pattern of darkly pigmented spots in what appears to be the same individual photographed in consecutive years. DS = dorsal "saddle" marking. Mexican Parrot Snake, Leptophis mexicanus hoeversi: (E) an individual observed in shrubs fringing manicured grounds edging the littoral forest (November 2013), (F) a close-up of dorsal scales in the snake shown in (E), $(G)$ a close-up of the head reveals the presence of the loreal scale (LO; November 2013), (H) an axanthic color morph found in the littoral forest fringing the walking trail exhibits a prominent ocular stripe (OS; December 2018). Photos by John R. Finnerty (A, B, D, E-H) and Justin Hall (C). 
Rhizophora mangle L. and Avicennia germinans L. The mangroves surround an interior lagoon that extends $\sim 500 \mathrm{~m}$ from north to south.

Species Accounts. Below, we list the species that we observed, and for those species that have not previously been documented from Calabash Caye, or any of the islands of Turneffe Atoll, we provide photographic documentation of traits used in species identification and the range of intraspecific variability we observed. Taxonomy follows The Reptile Database (Uetz et al., 2020), and common names follow Hedges et al. (2019). Only terrestrial herpetofauna are described here. However, we regularly observed American Crocodiles (Crocodylus acutus Cuvier 1807) in the surrounding waters and occasionally on the beach, and we have observed sea turtle nestlings on the beach, but did not approach them or attempt to identify them to species.

From 2012 to 2019, we photographed five lizards, three snakes, and one amphibian on Calabash Caye. Three of the lizards (Fig. 2) and two of the snakes (Fig. 3) were described previously as common on Calabash Caye or other islands of Turneffe Atoll (Henderson, 1976a; Zisman, 1992; Lee, 1996; Platt et al., 1999). These are the Common Spiny-Tailed Iguana (Ctenosaura similis Gray; Fig. 2A-D), Mayan Coastal Anole (Anolis sagrei mayensis Smith and Burger; Fig. 2E-F), Tuberculate Leaf-Toed Gecko (Phyllodactylus tuberculosus Wiegmann; Fig. 2G), Central American Boa Constrictor (Boa imperator Daudin; Fig. 3A-D), and a subspecies of the Mexican Parrot Snake endemic to Turneffe Atoll (Leptophis mexicanus hoeversi Henderson; Fig. 3E-H). Based on concordance in the pattern of dark spots on the head of Boa imperator (Fig. 3D), the same individual apparently was photographed in approximately the same trailside location in 2016 and 2017; this same technique for recognizing individual boas was employed in a previous survey of offshore Belizean cayes conducted in the early 2000s (Boback, 2005). We also managed to photograph a single L. m. hoeversi exhibiting the rarer, axanthic color morph (Fig. 3H) that appears bluish green (Platt et al., 1999; Stafford and Meyer, 2000; Meerman, 2006). At least one other axanthic individual was photographed on Calabash Caye prior to 2000 (Stafford and Meyer, 2000). Two lizards, one snake, and one amphibian that we observed have not been reported previously from Calabash Caye or any of the islands of Turneffe Atoll. These are described in greater detail below.

Cozumel Whiptail (Aspidoscelis cozumela). We photographed four adult Cozumel Whiptails, two in 2012 and one each in 2013 and 2019 (Fig. 4). In three instances, the lizards were in leaf litter adjacent to the beach (e.g., Fig. 4A,C) and, in one case, a lizard was along the margin of littoral forest (Fig. $4 \mathrm{E}-\mathrm{F}$ ). Aspidoscelis cozumela is a parthenogenetic species, commonly described as being endemic to Isla Cozumel, Mexico (Taylor and Cooley, 1995; Taylor et al., 2014). It has never been reported from any of the Belizean cayes. The individuals we photographed in 2012 and 2013 (Fig. $4 A, C)$ exhibit a yellowish-green cast, whereas the individual we photographed in 2019 exhibited a yellow-

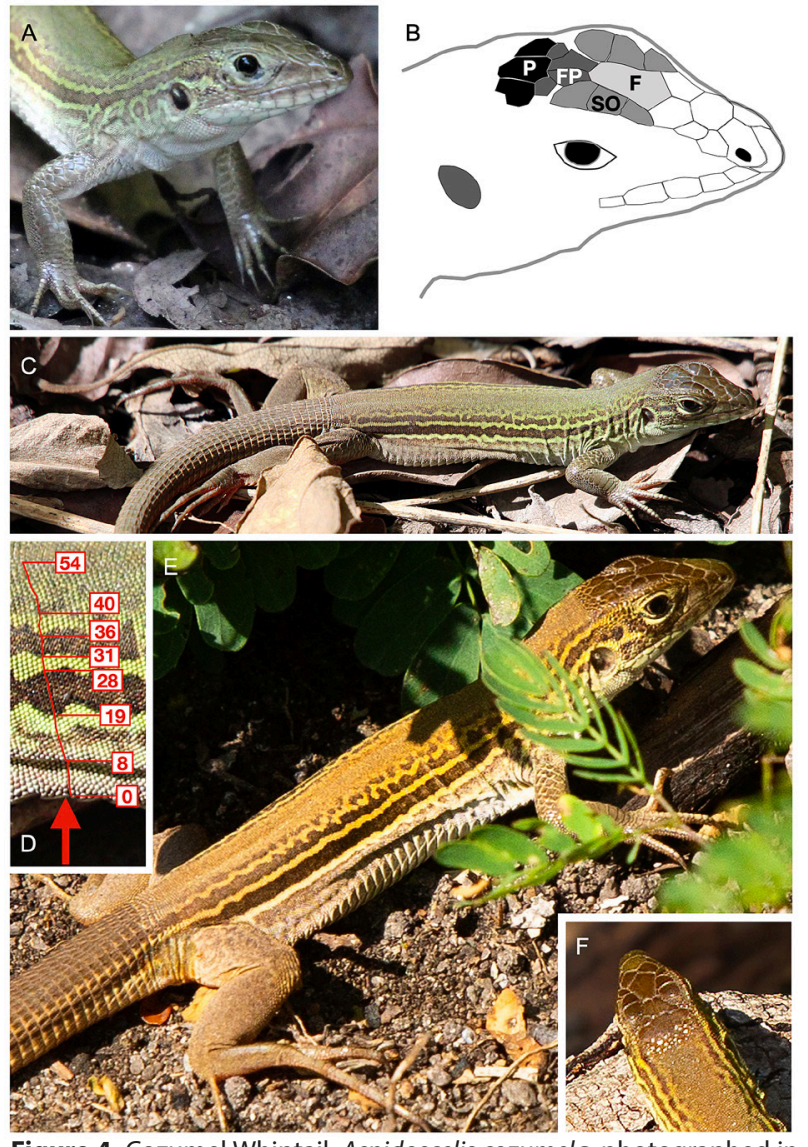

Figure 4. Cozumel Whiptail, Aspidoscelis cozumela, photographed in 2013 (A), 2012 (C), and 2019 (E,F). In two instances (A, C), individuals were crawling in leaf litter adjacent to the beach and, in one case $(E)$, the lizard was observed along the margin of caye/cocal forest (B). A tracing of the dorsal head scales of the individual shown in (C) illustrates the arrangement of frontal [F], supraocular [SO], frontoparietal $[F P]$, and parietal scales [P]. (D) Enlargement of the dorsal surface between the axilla and groin permits an approximate count of the dorsal granules. (F) Dorsal view of the head of the individual pictured in (E). Photos by John R. Finnerty (A, C, D) and Russell Laman (E, F). 
ish-orange cast (Fig. 4E,F). Along with A. maslini and A. rodecki, A. cozumela is a parthenogenetic species descended from hybridization of $A$. angusticeps and $A$. deppii. The three members of the $A$. cozumela species complex can be distinguished by the number of pale longitudinal dorsal stripes (Taylor et al., 2014). The adult A. rodecki lacks stripes, whereas A. maslini has eight and A. cozumela has six. Each of the individuals we photographed on Calabash has six stripes. The numbers of frontoparietals and dorsal granules visible in the photographs of the 2013 individual (Fig. 4B-C) are also consistent with A. cozumela.

Common House Gecko (Hemidactylus frenatus). Common House Geckos are routinely observed on Calabash Caye, chirping after dark on the inside and outside of edifices (Fig. 5A). Hemidactylus frenatus is a successful invasive species in tropical and subtropical habitats across the Old World that, in the last twenty years, has been reported in all of the mainland districts of Belize except the Toledo District (Stafford and Meyer, 2000; Rainwater and Platt, 2001). This represents the first report of $H$. frenatus from Turneffe Atoll or any of the offshore cayes.

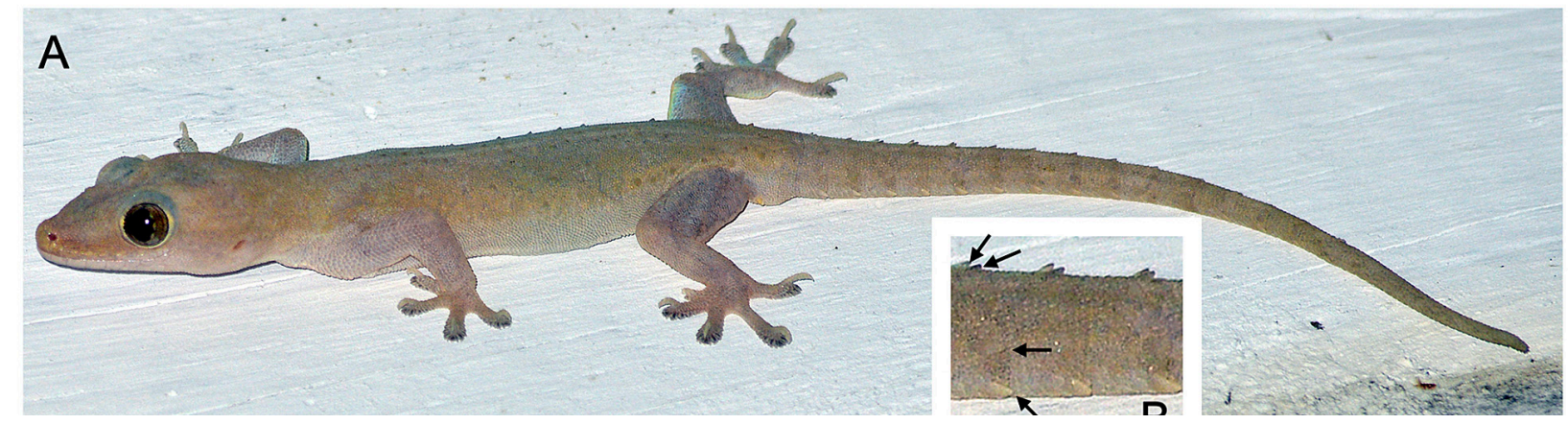

Figure 5. Common House Gecko, Hemidactylus frenatus, photographed in 2018 (A). (B) An enlargement of the dorsal surface of the base of the tail of the individual shown in (A). Arrows indicate four of six enlarged pointed scales belonging to the same caudal whorl. Photos by John R. Finnerty.

Schmidt's Black-striped Snake (Coniophanes schmidti). Each year from 2012 to 2018, we made fleeting observations of Faded Black-striped Snakes or Schmidt's Black-striped Snakes, almost exclusively at the sunny openings to the trail that passes through littoral forest along the southeastern shore of Calabash Caye. Individuals typically were sunning themselves atop dry leaf litter at the edge of the trail or climbing among the branches of woody shrubs. We did not manage to photograph any in the field, as they typically flee rapidly when approached. In 2013, a CCFS staff member collected, photographed, and subsequently released a single individual (Fig. 6). Coniophanes schmidti has been reported from numerous sites on the Yucatán Peninsula, Guatemala, and Belize (McCoy, 1969), but had not been reported from Turneffe Atoll or any of the Caribbean islands. The individual we photographed had a broad black dorsal stripe and 25 rows of dorsal scales in the anterior portion of the midbody, traits shared with other members of the Coniophanes piceivittis species group, which includes C. piceivittis, C. schmidti, C. taylori, and C. michoacanensis (Bailey, 1939; Harrison, 1992; Flores-Villela and Smith, 2009; Palacios-Aguilar and Flores-Villela, 2020). Other traits consistent with the C. picevittis species group include eight supralabials (Fig. 6B-C), with the fourth and fifth entering the orbit (Wilson and Meyer, 1985), and the combination of a large preocular and a small subpreocular (Palacios-Aguilar and Flores-Villela, 2020). The width of the median dorsal black stripe is five full scales plus two half-scales wide, a value that could be observed in either C. picevittis or C. schmidti (Flores-Villela and Smith, 2009). The thin lateral black stripes (one full-scale plus one half-scale in width) are consistent with $C$. schmidti but not C. picevittis (Bailey, 1939; Harrison, 1992; Flores-Villela and Smith, 2009).

Southern Gulf Coast Toad (Incilius valliceps). We observed multiple individuals of the Southern Gulf Coast Toad, Incilius valliceps (formerly Bufo valliceps) on Calabash Caye and were able to obtain photographs in 2013, 2017, 2018, and 2019 (Fig. 7). Typical of the species, all exhibited pronounced cranial crests, prominent parotoid glands approximately triangular in shape, a row of light-colored pointed warts down each side of the body from the parotoid glands to the groin, a dark lateral band immediately inferior to the row of warts, and a light-colored middorsal stripe (Porter, 1970; Lee, 2000). Across its range from Mexico's Gulf Coastal Plain to Costa Rica, I. valliceps is 


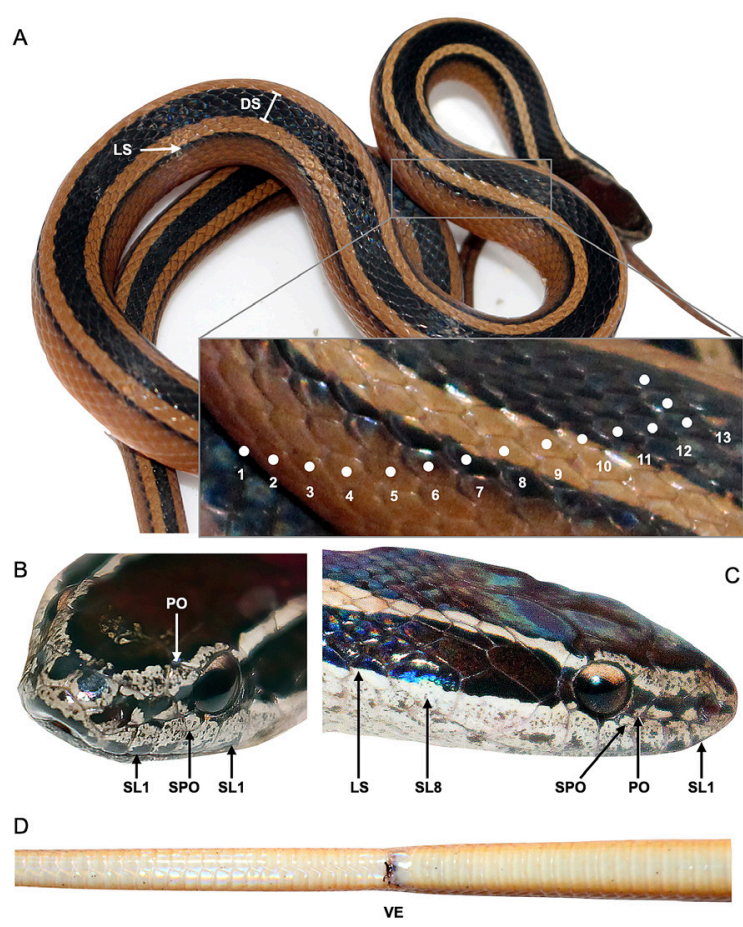

Figure 6. Schmidt's Black-striped Snake, Coniophanes schmidti, captured and released on 17 November 2013. (A) Dorsal view of the body revealing the dorsal and lateral stripes. A close-up of the image (inset) permits counting of dorsal scales. (B-C) Dorsolateral views of the head. (D) Ventral view of the vent region. Abbreviations are: $D S=$ dorsal stripe; $\mathrm{LS}=$ lateral stripe; $\mathrm{PO}=$ preocular; $\mathrm{SL}$ = supralabial; $\mathrm{SPO}$ = subpreocular. Photos by John R. Finnerty.

typically found in open or disturbed habitats (Mulcahy and Mendelson, 2000; Mendelson et al., 2015). At Calabash, these toads were most commonly observed after nightfall, in short vegetation adjacent to buildings or in the leaf litter at the edge of the littoral forest (Fig. $7 A, B, D)$. They could also be found during the day, sheltering beneath scrap lumber (Fig. 7E). The adults we observed exhibited a range of colors including tan, brown, gray, and black, and estimated snout-vent lengths (SVLs) in the range of 6-7 cm. We occasionally observed much smaller toads ( 2-3 cm SVL) sharing some features with adult I. valliceps, including a lateral row of warts located dorsal to a darkly colored band, but lacking prominent cranial crests and parotoid glands (Fig. 7C). These small toads are thought to be newly metamorphosed individuals that had not yet developed all of the distinctive features of the adult (personal communication, J. Wiens, U. Arizona).

Half Moon Caye. During three one-day excursions to Half Moon Caye (Fig. 8A-B) conducted in 2013, 2014, and 2017, we photographed three lizard species. Half Moon Caye is a simple sand caye on the southeastern edge of Lighthouse Reef Atoll (Stoddart, 1962), located approximately 31 km ESE of Calabash Caye. All three species were photographed along the edge of broadleaf forest dominated by Cordia sebestena that is home to a large nesting colony of Red-footed Boobies (Sula sula L.). On the ground along a walking trail, we photographed large adult Ctenosaura similis, both female (Fig. 8C) and male (Fig. 8D). Perched on a tree branch amid the S. sula colony, we observed a single Cuban Blue Anole (Anolis allisoni Barbour 1928; Fig. 8E-F). By far the most abundant lizard we observed was A. sagrei mayensis (Fig. $8 \mathrm{G}-\mathrm{H}$ ). All three of these species have been previously reported in multiple 

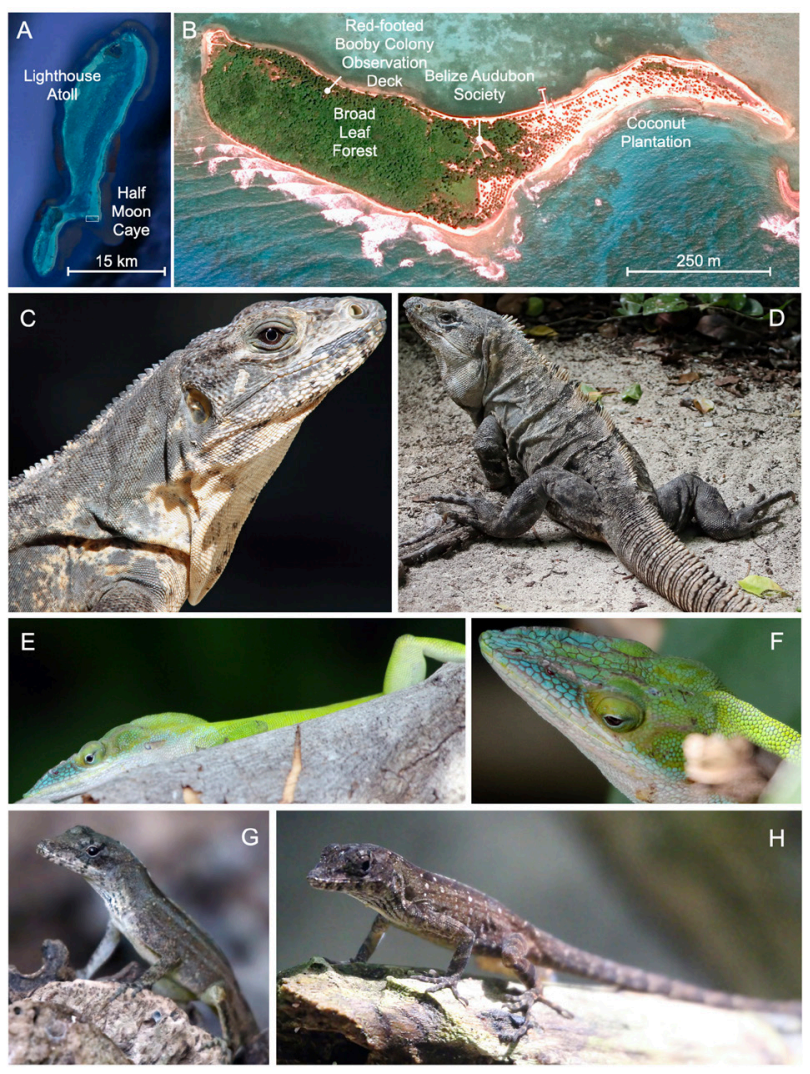

Figure 8. Lizards of Half Moon Caye. Satellite views of (A) Lighthouse Reef Atoll and (B) Half Moon Caye. (C) Adult female Ctenosaura similis, November 2014; (D) Adult male Ctenosaura similis, December 2017; (E) Anolis allisoni, December 2017; (F) Dorsal view of the head of the individual shown in (E); $(G, H)$ Anolis sagrei mayensis photographed in November 2014 (G) and November 2013 (H). Satellite images (A, B) obtained by Landsat/Copernicus and accessed using Google Earth Pro (v. 7.3.2.5776). Images @ 2021 Maxar Technologies. Photos by John R. Finnerty (C-H).

herpetological inventories from Half Moon Caye (Schmidt, 1941; Verner, 1959; Meerman, 1996; Platt et al., 1999). We did not observe Green Iguanas (Iguana iguana Linnaeus 1758), which had been reported in prior surveys (Schmidt, 1941; Verner, 1959; Meerman, 1996; Platt et al., 1999), but our photographic sampling did not extend beyond the vicinity of the waking trail along the northwestern margin of the island (Fig. 8B). Consistent with the more recent reports (Meerman, 1996; Platt et al., 1999), we did not observe any juvenile C. similis.

Site Comparisons. To relate our observations to previous studies from islands in the western Caribbean, we clustered sites based upon the shared presence and absence of species using a principal coordinates analysis performed using the R statistical computing environment, version 4.1.0 (R Software Team, 2017). Based on the species records summarized in Table 1, we computed simple matching distances between all pairs of sites using the "dissimilarity" function (method = "matching") in the arules package (version 1.6.6). We then conducted a principal coordinates analysis (PCoA) with this dissimilarity matrix using the "pcoa" function in the ape package (version
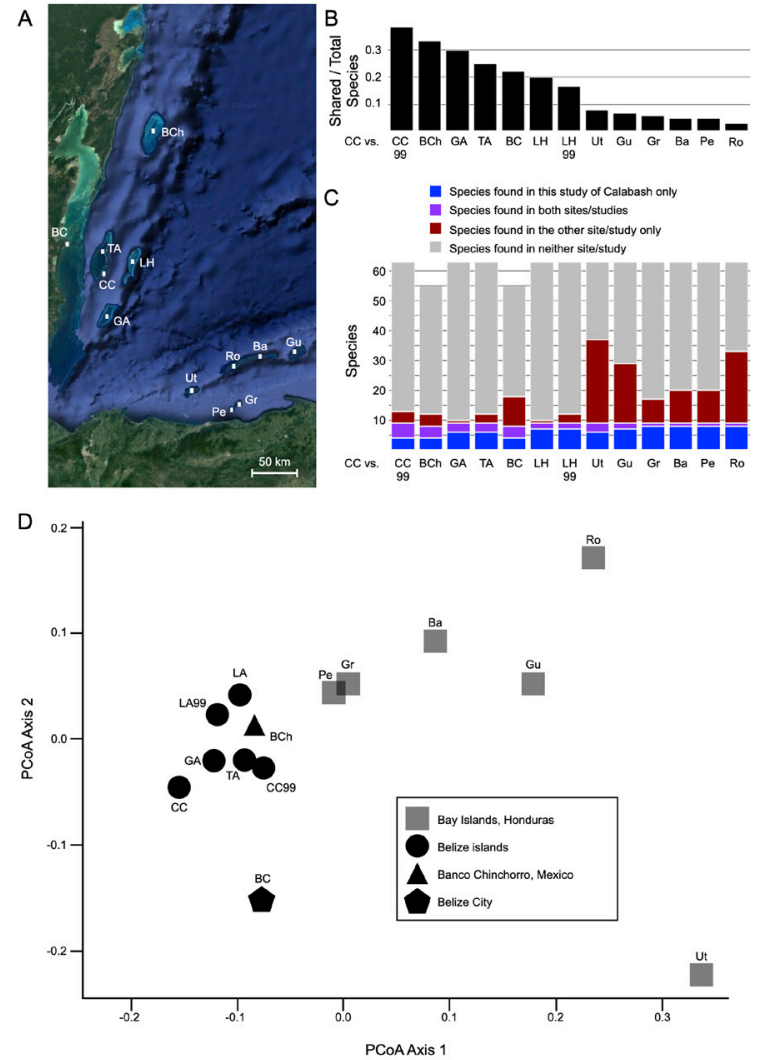

Figure 9. Comparison of the Calabash herpetofauna with that of other western Caribbean islands and Belize City. (A) Satellite view and accessed using Google Earth Pro (v. 7.3.2.5776). Images ๑ 2021 Maxar Technologies. (B) Fraction of taxa that are shared between this study of Calabash Caye and other sites/studies. All taxa listed in Table neither site in pairwise comparisons with the Calabash Caye species documented in this study. All taxa listed in Table 1 are included in the analysis. (D) Principal coordinates analysis of sites based on simple matching distance. All taxa listed in Table 1 are included in the analysis except for amphibians, which were not recorded in the studies of Belize City or Banco Chinchorro. Abbreviations of sites: $\mathrm{Ba}=\mathrm{Isla}$ de Barbareta, HN; BC = Belize City; BCh = Banco Chinchorro, MX; CC = Calabash Caye, BZ (present study); CC99 = Calabash Caye, BZ (Platt et al., 1999); GA = Glover's Atoll, BZ; Gr = Cayo Cochino Grande, HN; Gu = Isla de Guanaja, HN; LH = Lighthouse Reef Atoll, BZ (present study); LH99 = Lighthouse Reef Atoll, BZ (Platt et al., 1999); Pe = Cayo Cochino Pequeño; Ro = Isla de Roatán, HN; TA = Turneffe Atoll, BZ (other than Calabash Caye); Ut = Isla de Utila, $\mathrm{HN}$. of the western Caribbean. Images obtained by Landsat/Copernicus 1 are included in the analysis. (C) Taxa found in one site, both sites, or 
Table 1. Comparison of herpetological species records from islands in the western Caribbean. Species photographed at Calabash Caye in this study are shaded in blue. Species not photographed at Calabash Caye in this study are shaded gray. Abbreviations: BI = Bay Islands; $\mathrm{TA}$ =Turneffe Atoll; Study: 1 = this study; 2 = (Henderson, 1976b); 3 =(Platt et al., 1999); 4 =(Charruau et al., 2015); 5 =(McCranie et al., 2005).

\begin{tabular}{|c|c|c|c|c|c|c|c|c|c|c|c|c|c|c|c|}
\hline & Locale & 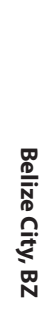 & 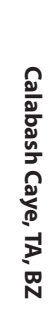 & 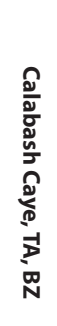 & 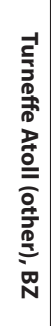 & 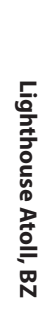 & 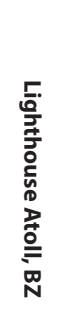 & 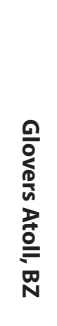 & 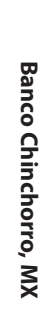 & 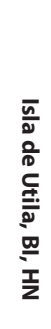 & 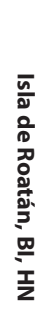 & 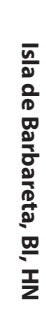 & 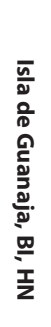 & 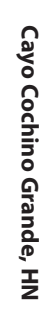 & 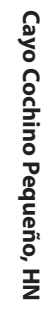 \\
\hline & Study & 2 & 1 & 3 & 3 & 1 & 3 & 3 & 4 & 5 & 5 & 5 & 5 & 5 & 5 \\
\hline LIZARDS & & & & & & & & & & & & & & & \\
\hline Anolis allisoni & & & & & & $\mathbf{x}$ & & & $\mathbf{x}$ & & $\mathbf{x}$ & $\mathbf{x}$ & $\mathbf{x}$ & $\mathbf{x}$ & $\mathbf{x}$ \\
\hline Anolis bicaorum & & & & & & & & & & $\mathrm{x}$ & & & & & \\
\hline Anolis lemurinus & & $\mathbf{x}$ & & & & & & & & & & & & $\mathbf{x}$ & $\mathbf{x}$ \\
\hline Anolis roatanensis & & & & & & & & & & & $\mathbf{x}$ & & & & \\
\hline Anolis sagrei mayensis & & $\mathbf{x}$ & $\mathbf{x}$ & $\mathbf{x}$ & $\mathbf{x}$ & $\mathbf{x}$ & $\mathbf{x}$ & $\mathbf{x}$ & $x$ & & $\mathbf{x}$ & & & & \\
\hline Anolis sericeus & & & & & & & & & & $\mathbf{x}$ & & & & & \\
\hline Anolis utilensis & & & & & & & & & & $\mathbf{x}$ & & & & & \\
\hline Aristelliger georgeensis & & & & & & & & & $\mathbf{x}$ & & & & & & \\
\hline Aspidoscelis cozumela & & & $\mathbf{x}$ & & & & & & & & & & & & \\
\hline Aspidoscelis maslini & & & & & & & & & $\mathbf{x}$ & & & & & & \\
\hline Basiliscus vittatus & & $\mathbf{x}$ & & $\mathbf{x}$ & $\mathbf{x}$ & & & & & $\mathbf{x}$ & $\mathbf{x}$ & $\mathbf{x}$ & $\mathbf{x}$ & $\mathbf{x}$ & \\
\hline Cnemidophorus lemniscatus & & & & & & & & & & $\mathbf{x}$ & $\mathbf{x}$ & & & & $\mathbf{x}$ \\
\hline Coleonyx mitratus & & & & & & & & & & $\mathbf{x}$ & & & & & \\
\hline Ctenosaura bakeri & & & & & & & & & & $\mathrm{x}$ & & & & & \\
\hline Ctenosaura melanosterna & & & & & & & & & & & & & & $\mathbf{x}$ & $\mathbf{x}$ \\
\hline Ctenosaura oedirhina & & & & & & & & & & & $\mathbf{x}$ & $\mathbf{x}$ & & & \\
\hline Ctenosaura similis & & $\mathbf{x}$ & $\mathbf{x}$ & $\mathbf{x}$ & $\mathbf{x}$ & $\mathbf{x}$ & $\mathbf{x}$ & $\mathbf{x}$ & $\mathbf{x}$ & $\mathbf{x}$ & & & $\mathbf{x}$ & & \\
\hline Gymnophthalmus speciosus & & & & & & & & & & & $\mathbf{x}$ & $\mathbf{x}$ & $\mathbf{x}$ & & \\
\hline Hemidactylus frenatus & & & $\mathbf{x}$ & & & & & & $\mathbf{x}$ & $\mathrm{x}$ & & & & & \\
\hline Iguanaiguana & & $\mathrm{x}$ & & & & & $\mathbf{x}$ & $\mathbf{x}$ & $\mathbf{x}$ & $\mathrm{x}$ & $\mathrm{x}$ & $\mathbf{x}$ & $\mathbf{x}$ & & $\mathbf{x}$ \\
\hline Mabuya brachypoda & & $\mathbf{x}$ & & & & & & & & & & & & & \\
\hline Mabuya unimarginata & & & & $\mathbf{x}$ & $\mathbf{x}$ & & & & & $\mathbf{x}$ & $\mathbf{x}$ & & $\mathbf{x}$ & & \\
\hline Phyllodactylus insularis & & $\mathbf{x}$ & & & & & $\mathbf{x}$ & $\mathbf{x}$ & & & & & & & \\
\hline Phyllodactylus palmeus & & & & & & & & & & $\mathbf{x}$ & $\mathrm{x}$ & $\mathrm{x}$ & $\mathbf{x}$ & $\mathbf{x}$ & $\mathbf{x}$ \\
\hline Phyllodactylus tuberculosis & & $\mathbf{x}$ & $\mathbf{x}$ & $\mathbf{x}$ & $\mathbf{x}$ & & $\mathbf{x}$ & $\mathbf{x}$ & & & & & & & \\
\hline Sphaerodactylus millepunctatus & & & & & & & & & & $\mathbf{x}$ & $\mathbf{x}$ & $\mathbf{x}$ & $\mathbf{x}$ & & \\
\hline Sphaerodactylus rosaurae & & & & & & & & & & $\mathbf{x}$ & $\mathrm{x}$ & $\mathbf{x}$ & $\mathbf{x}$ & & \\
\hline Scincella cherriei & & & & & & & & & & & & & & & $\mathbf{x}$ \\
\hline Thecadactylus rapicauda & & & & & & & & & & $\mathbf{x}$ & & & & & \\
\hline SNAKES & & & & & & & & & & & & & & & \\
\hline Boa imperator & & $\mathbf{x}$ & $\mathbf{x}$ & $\mathbf{x}$ & & & & & $\mathbf{x}$ & $\mathbf{x}$ & $\mathbf{x}$ & $\mathrm{x}$ & $\mathbf{x}$ & $\mathbf{x}$ & $\mathbf{x}$ \\
\hline Coniophanes bipunctatus & & & & & & & & & & & $\mathbf{x}$ & & & & \\
\hline Coniophanes imperialis & & $\mathbf{x}$ & & & & & & & & $\mathbf{x}$ & & & & & $\mathbf{x}$ \\
\hline
\end{tabular}




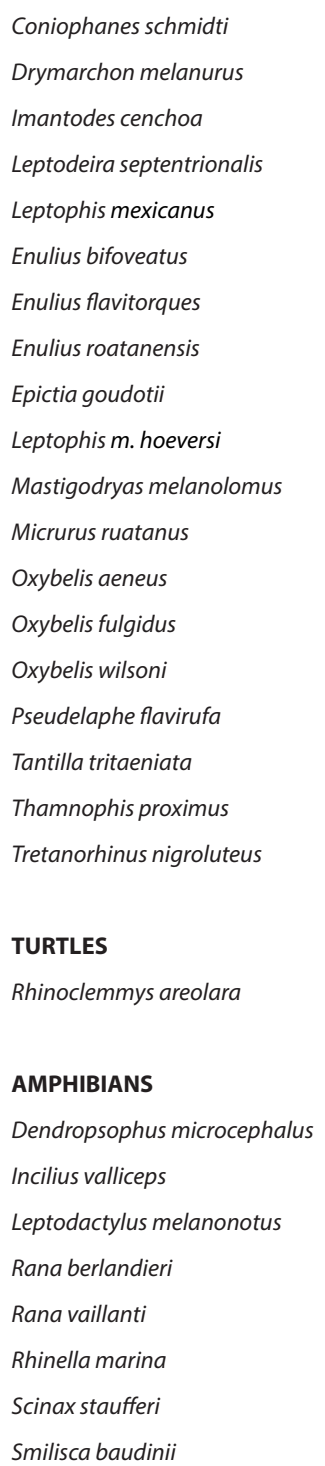
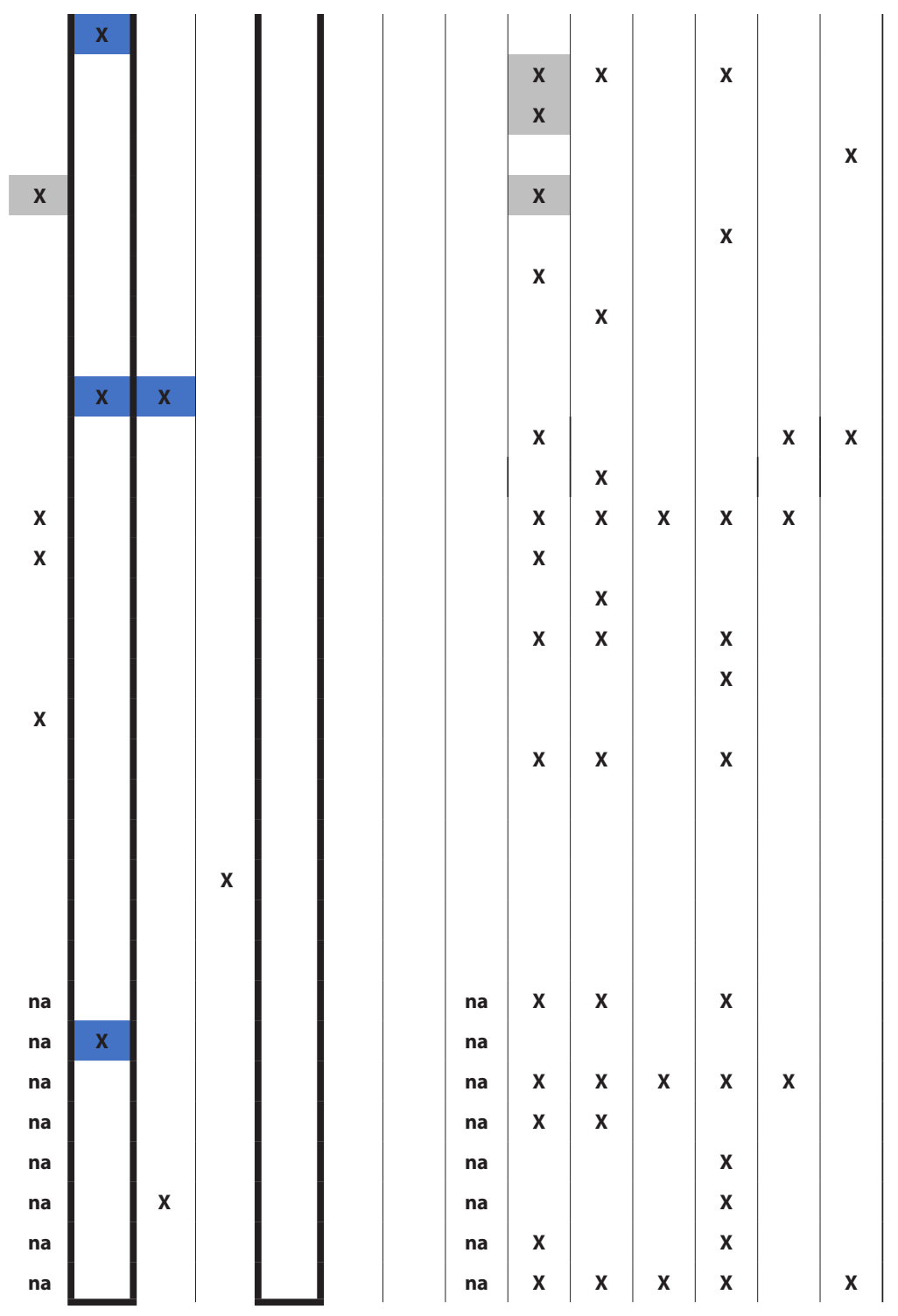

5.4.1) and plotted the first two axes using the "plot" function in the R graphics package (version 4.0.4).

We compared our photograph-based inventory of the herpetofauna of Calabash Caye to published inventories of nearby locales with similar environments (Table 1; Fig. 9A), as well as the only published inventory for Calabash Caye itself, which was compiled in the 1990s (Platt et al., 1999). In addition to the islands of Turneffe, Platt and coworkers compiled species lists for Glovers and Lighthouse Atolls. Half Moon Caye on Lighthouse Atoll has been the focus of several herpetological surveys (Schmidt, 1941; Verner, 1959; Meerman, 1996; Platt et al., 1999). Henderson conducted extensive observations of reptiles in Belize City between July 1970 and July 1971 (Henderson, 1973, 1974b, a, 1976b). Belize City lies approximately $33 \mathrm{~km}$ to the northwest of Calabash Caye. Frequent boat traffic between the two locations speaks to the possibility of anthropogenic introductions. Charruau and co-workers compiled a species list of the reptile fauna of Banco Chinchorro, an atoll whose main landmass is located approximately $42 \mathrm{~km}$ from the coast of Quintana Roo, Mexico, and approximately $156 \mathrm{~km}$ north of Calabash Caye. They used a combination of approaches, including interviews with scientists and fishermen, a review of the literature and previously collected specimens, as well as fieldwork conducted between 2011 and 2013 (Charruau et al. , 2015). A number of herpetological surveys were conducted in the Bay Islands (Utila, Roatán, Barbareta, Guanaja) and Cayos Cochinos, off the coast of Honduras, from the late 1960s through the early 2000s (Wilson and Hahn, 
1973; Wilson and Cruz Diaz, 1993; McCranie et al., 2005). The closest of these islands is approximately $160 \mathrm{~km}$ southeast of Calabash Caye and the islands range from approximately 30 to $70 \mathrm{~km}$ north of the coast of Honduras.

Overall, the species list compiled for Calabash Caye in this study exhibits the greatest overlap with the species list compiled for Calabash Caye in the 1990s, is somewhat less similar to Banco Chinchorro, Mexico, and the other Belizean islands, and bears the least resemblance to the Bay Islands of Honduras (Fig. 9B-C). A principal coordinates analysis based on simple matching distance (which considers both the shared presence and the shared absence of taxa) revealed a tight clustering of the Belizean island herpetofaunas with that of Banco Chinchorro, Mexico (Fig. 9D).

Previously reported species that were not observed. We failed to observe two lizards, one toad, and a snake that have previously been reported on Calabash Caye (Platt et al., 1999). Two of these species-the Mayan Skink, Marisora lineola (McCranie et al., 2020; formerly Mabuya unimarginata) and a blindsnake provisionally identified as Indotyphlops braminus (Daudin 1803; formerly Ramphotyphlops braminus)—are commonly hidden beneath the substrate and were described as rare on Calabash. For these reasons, our opportunistic photo-surveys were likely to have missed them. However, the remaining two members of the herpetofauna that we failed to observe-the Mesoamerican Cane Toad (Rhinella horribilis L.) and Brown Basilisk (Basiliscus vittata Wiegmann) —are likely to have been captured by our surveys if present on Calabash during 2012 to 2019.

The only amphibian previously reported on any of the Belizean atolls is the Cane Toad, Rhinella marina (formerly Bufo marinus L.). A single individual was reported on Calabash Caye in 1995, and another in 1997 (Platt et al., 1999). A recent taxonomic revision of Rhinella based on molecular phylogenetic and morphometric analyses indicated a clear division between the South American Cane Toad (R. marina), which can be found east of the Andes, and the Mesoamerican Cane Toad (R. horribilis Wiegmann, 1833), which occurs west of the Andes and throughout Central America (Vallinoto et al., 2010; Acevedo et al., 2016; Hedges et al., 2019). Presumably, any cane toads identified on the Belizean cayes would be $R$. horribilis. We did not observe $R$. horribilis over the course of our surveys from 2012 to 2019. If present in abundance, Mesoamerican Cane Toads would likely be a conspicuous component of the herpetofauna on Calabash. Like Incilius valliceps, R. horribilis tends to occupy disturbed areas near human habitation, but it is substantially larger than I. valliceps, e.g., SVL 80-210 versus 73-100 mm (Lee, 2000). Furthermore, whereas $R$. horribilis is broadly sympatric with I. valliceps on the Belizean mainland, even at the lower end of the size range for cane toads, I. valliceps can be distinguished from $R$. horribilis by the relatively smaller size of the parotoid glands, the row of pointy warts running down each side of the body, the dark lateral stripe, and distinct differences in the arrangement of cranial crests (Porter, 1970; Zug and Zug, 1979; Meyer and Foster, 1996; Lee, 2000; Somma, 2019).

The other conspicuous species previously reported from Calabash Caye is the Brown Basilisk (Basiliscus vittatus Wiegmann, 1828), which was described as common in beach scrub and littoral forest habitats on Calabash Caye and Blackbird Caye, the neighboring island to the north (Platt et al., 1999). The report of Brown Basilisks on Calabash and Blackbird represents the only report of this species from Turneffe Atoll. Given its size (males can exceed $60 \mathrm{~cm}$ from the tip of the snout to the tail) and distinctive appearance, including a prominent tri-partite dorsal crest and bright white lateral stripes on the head, the failure to observe this diurnally active lizard over eight consecutive years (2012-2019) suggests that it has become greatly diminished in abundance since the previous report in 1999, if not absent from Calabash Caye altogether.

Conservation implications. Given its habitat diversity and history of human utilization, Calabash Caye provides a critical window into the herpetological diversity of Turneffe Atoll. The elevated beach ridge along the eastern edge of Turneffe Atoll enables the formation of strand plain plant communities and littoral forest, which are critical habitats for the herpetofauna described here. However, these same habitats are attractive sites for human development. Turneffe has a long history of human occupation, as evidenced by Mayan shell-middens found in the vicinity of Calabash Caye (Romney et al., 1959). More recently, Turneffe has been a focus of intensive agricultural activity. In the early 1900 s, many of the eastern cayes of Turneffe Atoll were heavily populated by domesticated animals, 
primarily chickens, dogs, and pigs. Calabash housed the largest "piggery" (Stoddart, 1963) and until 1961 was home to a warehouse and collection center serving the coconut industry (Platt et al., 1999). Accompanying the people and their domesticated animals, rats became a major pest. This history of heavy human utilization profoundly altered the habitats and introduced many non-native plant and animal species, both of which would have impacted the native herpetofauna.

Among the herpetofauna we documented, only the Common House Gecko is clearly not native to Turneffe. Introduced from Asia and the Indo-Pacific (Farr, 2011), H. frenatus quickly spread through Central America, with the first recorded sighting in Belize in the 1990s (Meerman and Garel, 2002). Its aggressive and territorial behavior, coupled with its ability to successfully inhabit heavily developed areas allowed this species to competitively displace native, endemic gecko species, such as the Tuberculate Leaf-toed Gecko (Cole et al., 2005; Farr, 2011). Little research has been conducted on the interactions of $H$. frenatus with native geckos in Central America, including Belize, although Powell (2003) noted observations of H. frenatus displacing the Honduran Leaf-toed Gecko (Phyllodactylus palmeus Dixon 1968) on the island of Utila.

The greatest threat to the terrestrial biodiversity of Calabash and other islands of eastern Turneffe is habitat loss, particularly the loss of littoral forest (Platt et al., 1999). Until the early 1960s, coconut plantations blanketed the elevated beach ridges along the eastern edge of Turneffe Atoll, including the entire sandy eastern third of Calabash (see Stoddart, 1962, Fig. 14). As littoral forest is restricted to these sandy elevations, coconut palms effectively displace the native habitat and the fauna that depends on it. However, the coconut industry on Turneffe was decimated in 1962 by Hurricane Hattie, which destroyed much of the infrastructure that supported it, including the warehouse and collection center at Calabash (Stoddart, 1963). With the sharp reduction of coconut palms in the northern portion of Calabash Caye, the littoral forest has recovered to some degree, and the principal present-day occupants of the island - the Belize Coast Guard, Calabash Caye Field Station, and Turneffe Atoll Sustainability Association-undoubtedly have a protective effect on the island's biodiversity by discouraging illegal exploitation. However, only a small fraction of the original extent of littoral forest likely remains. Further decline will not only contribute directly to losses in local species abundance and/or richness by destruction of habitat, but also indirectly by exacerbating inter- and intra-specific competition among species. Consequently, protection of the remaining littoral forest on Calabash and on the other cayes comprising the Atoll is critical to maintaining herpetofaunal biodiversity. Such action is concordant with Belize's target of protecting $10 \%$ of coastal and marine areas that include littoral forests and beach vegetation (Turneffe Atoll Sustainability Association, 2020). Of note, when the prior species inventory of the atoll was published (Platt et al., 1999), Turneffe was not protected, but in November 2012, the Turneffe Atoll Marine Reserve was formed. The protection of littoral forest was nested under conservation targets for "terrestrial ecosystems" (Turneffe Atoll Management Plan 2012-2017).

Given the scarcity of particular habitats and the small size of many offshore cayes (including Calabash), the effective population sizes of island reptiles and amphibians will tend to be much smaller than mainland populations, and this alone generates conservation concerns. As Boback (2005) pointed out, island boas off the coast of Belize can be classified as Endangered according to IUCN criteria based on their small population sizes alone. Given this, non-destructive photo-surveys such as the current study could prove critical to monitoring herpetofaunal biodiversity. Such studies, even when conducted by non-experts, can be effective at monitoring common and conspicuous species.

\section{Conclusions}

The current study documents a snake, two lizards, and a toad on Calabash Caye that have not previously been reported from Turneffe Atoll: Schmidt's Striped Snake, Coniophanes schmidti; Common House Gecko, Hemidactylus frenatus; Cozumel Whiptail, Aspidoscelis cozumela; and Southern Gulf Coast Toad, Incilius valliceps. In each instance, we were able to identify diagnostic anatomical features from photographs. Except for Common House Gecko, each of these species was photographed in multiple years. 


\section{Acknowledgements}

The opportunity to photograph the terrestrial herpetofauna of Calabash Caye was an outgrowth of Boston University's annual research trips to the Calabash Caye Marine Station undertaken between 2012 and 2019. These field trips and the marine research projects that motivated them were made possible by the Boston University Marine Program through its Marine Semester, and by the Belize Fisheries Department, which supplied the Aquatic Scientific Research Permits under which the research was conducted. We thank the staff of the Boston University Marine Program, specifically Julia Hammer-Mendez, Jonathan Perry, and Justin Scace, for their logistical and technical support of the Marine Semester. We also thank the Belize Fisheries Department, especially Mauro Gongora and Felicia Cruz, for assistance in obtaining research permits that enabled our presence at the station. We are extremely grateful for the natural history expertise of staff at the Calabash Caye Field Station, who assisted us in spotting the herpetofauna whose photographs are presented here. In particular, we thank Chris Encalada for guided nature tours, Nacho Cortez and Rene Coc for help in spotting snakes and lizards, and Justin Hall for photos and video of Boa imperator consuming a grackle. We are also grateful to the Bertarelli Foundation and the Oak Foundation for their contributions to the research infrastructure at Calabash Caye Field Station. The manuscript was greatly improved through suggestions provided by Robert W. Henderson (Milwaukee Public Museum) and Harry L. Taylor (American Museum of Natural History). HLT also confirmed the identity of $A$. cozumela, and RWH confirmed the identity of C. similis, H. frenatus, P. tuberculosus, B. imperator, C. schmidti, I. valliceps, and L. m. hoeversi.

\section{References}

Acevedo AA, Lampo M, Cipriani R (2016) The cane or marine toad, Rhinella marina (Anura, Bufonidae): two genetically and morphologically distinct species. Zootaxa, 4103, 574-586. Article

Bailey JR (1939) A systematic study of the snakes of the genus Coniophanes. Papers of the Michigan Academy of Sciences, Arts and Letters, 24, 1-48.

Boback SM (2005) Natural history and convservation of island boas (Boa constrictor) in Belize. Copeia, 2005, 880885. Article

Charruau P, de la Vega Pérez AH, Méndez de la Cruz FR (2015) Reptiles of Banco Chinchorro: Updated list, life history data, and conservation. Southwest Naturalist, 60, 299-312. Article

Cole NC, Jones CG, Harris S (2005) The need for enemy-free space: The impact of an invasive gecko on island endemics. Biological Conservation, 125, 467-474. Article

Farr WL (2011) Distribution of Hemidactylus frenatus in Mexico. Southwest Naturalist, 56, 265-273. Article

Flores-Villela O, Smith EN (2009) A new species of Coniophanes (Squamata: Colubridae) from the coast of Michoacán, Mexico. Herpetologica, 65, 404-412. Article

Fosberg FR, Stoddart DR, Sachet M-H, Spellman DL (1982) Plants of the Belize cays. Atoll Research Bulletin, 258, 1-77. Harrison CR (1992) A taxonomic revision of the snakes in the Coniophanes piceivittis species group, University of Texas El Paso Masters Thesis.

Hedges SB, Powell R, Henderson RW, Hanson S, Murphy JC (2019) Definition of the Caribbean Islands biogeographic region, with checklist and recommendations for standardized common names of amphibians and reptiles. Caribbean Herpetology. Article

Henderson RW (1973) Ethoecological observations of Ctenosaura similis (Sauria: Iguanidae) in Honduras. Journal of Herpetology, 7, 27-33.

Henderson RW (1974a) Aspects of the ecology of the juvenile common iguana (Iguana iguana). Herpetologica, 30, 327-332.

Henderson RW (1974b) Aspects of the ecology of the Neotropical vine snake, Oxybelis aeneus. Herpetologica, 30, $19-24$.

Henderson RW (1976a) A new insular subspecies of the colubrid snake Leptophis mexicanus (Reptilia, Serpentes, Colubridae) from Belize. Journal of Herpetology, 10, 329-331. 
Henderson RW (1976b) Notes on reptiles in the Belize City, Belize area. Journal of Herpetology, 10, 143-146.

Lee JC (1996) The Amphibians and Reptiles of the Yucatán Peninsula (Comstock Publishing Associates, Ithaca, New York)

Lee JC (2000) A Field Guide to the Amphibians and Reptiles of the Maya World (Cornell University Press, Ithaca)

McCoy CJ (1969) Snakes of the genus Coniophanes (Colubridae) from the Yucatán Peninsula, México. Copeia, 4, 847-849.

McCranie JR, Matthews AJ, Hedges SB (2020) A morphological and molecular revision of lizards of the genus Marisora Hedges (Squamata: Mabuyidae) from Central America and Mexico, with descriptions of four new species. Zootaxa, 4763, 301-353. Article

McCranie JR, Wilson LD, Köhler G (2005) Amphibians \& Reptiles of the Bay Islands and Cayos Cochinos, Honduras (Bibliomania!, Singapore)

Meerman JC (1996) Half Moon Caye, Belize. Terrestrial survey results and management implications (Belize Audubon Society, Belize City, BZ)

Meerman JC (2006) Mangrove and conservation value assessment at northern Turneffe (Belize Forest Department of the Ministry of Natural Resources, Belize City, BZ)

Meerman JC, Garel J (2002) Tokay Gecko Gekko gecko (L) established on South Water Caye, Belize. Available at http:// www.biological-diversity.info/tokay.htm. Accessed 24 May 2021.

Mendelson JR, Kinsey CT, Murphy JB (2015) A review of the biology and literature of the Gulf Coast Toad (Incilius nebulifer), native to Mexico and the United States. Zootaxa, 3974, 517-537. Article

Meyer JR, Foster CF (1996) A Guide to the Frogs and Toads of Belize (Krieger Publishing, Malabar, FL)

Mulcahy DG, Mendelson JR (2000) Phylogeography and speciation of the morphologically variable, widespread species Bufo valliceps, based on molecular evidence from mtDNA. Molecular Phylogenetics and Evolution, 17, 173-189. Article

Palacios-Aguilar R, Flores-Villela O (2020) Taxonomic revision and comments on two groups of the genus Coniophanes (Squamata: Dipsadidae). Vertebrate Zoology, 70, 111-124. Article

Platt SG, Meerman JC, Rainwater TR (1999) Diversity, observations, and conservation of the herpetofauna of Turneffe, Lighthouse, and Glovers Atolls, Belize. British Herpetological Society Bulletin, 66, 1-13.

Porter KR (1970) Bufo valliceps Wiegman Gulf Coast toad. Catalogue of American Amphibians and Reptiles, 94, 1-4.

Powell R (2003) Species Profile: Utila's reptiles. Iguana, 10, 36-37.

R Software Team (2017) R: A language and environment for statistical computing (R Foundation for Statistical Computing, Vienna, Austria)

Rainwater TR, Platt SC (2001) Geographic distribution: Hemidactylus frenatus. Herpetological Review, 32, 118.

Romney DH, Wright ACS, Arbuckle HH, Vial VS (1959) Land in British Honduras (British Honduras Land Use Survey Team, London)

Schmidt KP (1941) The amphibians and reptiles of British Honduras. Field Museum of Natural History. Zoological Series, 22, 475-510.

Somma LA (2019) Rhinella marina (Linnaeus, 1758). Available at https://nas.er.usgs.gov/queries/factsheet.aspx?SpeciesID=48. Accessed September 292021.

Stafford PJ, Meyer JR (2000) A Guide to the Reptiles of Belize (Academic Press, San Diego)

Stoddart DR (1962) Three Caribbean atolls: Turneffe Islands, Lighthouse Reef and Glovers Reef British Honduras. Atoll Research Bulletin, 87, 1-151.

Stoddart DR (1963) Effects of Hurricane Hattie on the British Honduras reefs and cays, October 30-31, 1961. Atoll Research Bulletin, 95, 1-145.

Taylor HL, Cole CJ, Cooley CR (2014) Origins and evolution in the Aspidoscelis cozumela complex of parthenogenetic teiid lizards: Morphological and karyotypic evidence and paradoxes. Journal of Herpetology, 48, 343-354.

\section{Article}


Taylor HL, Cooley CR (1995) A multivariate analysis of morphological variation among parthenogenetic teiid lizards of the Cnemidophorus cozumela complex. Herpetologica, 51, 67-76.

Turneffe Atoll Sustainability Association (2020) Turneffe Atoll Marine Reserve Ecosystems. Available at http://www. turneffeatollmarinereserve.org/habitats. Accessed May 242021.

Uetz Pe, Freed Pe, Hošek Je (2020) The Reptile Database. Available at http://www.reptile-database.org. Accessed January 62021.

Vallinoto M, Sequeira F, Sodré D, Bernardi JAR, Sampaio I, Schneider H (2010) Phylogeny and biogeography of the Rhinella marina species complex (Amphibia, Bufonidae) revisited: implications for Neotropical diversification hypotheses. Zoologica Scripta, 39, 128-140. Article

Verner J (1959) Behaviour of the red-footed booby (Sula sula) in British Honduras., Louisiana State University Masters Thesis, Baton Rouge.

Wilson LD, Cruz Diaz GA (1993) The herpetofauna of the Cayos Cochinos, Honduras. Herpetological Natural History, $1,13-23$.

Wilson LD, Hahn DE (1973) The herpetofauna of the Islas de la Bahia, Honduras. Bulletin of the Florida State Museum. Biological Sciences Series, 17, 93-150.

Wilson LD, Meyer JR (1985) The Snakes of Honduras (Milwaukee Public Museum, Milwaukee, Wisconsin)

Zisman S (1992) Mangroves in Belize: Their characteristics, uses and conservation. (Ministry of Natural Resources Belmopan, Belize)

Zug GR, Zug PB (1979) The marine toad, Bufo marinus: A natural history resumé of native populations. Pp. 58 in Smithsonian Contributions to Zoology Smithsonian Institution Press, Washington DC. 